\title{
EFFECT OF DEPTH OF TILLAGE ON SOIL PHYSICAL CONDITIONS, GROWTH AND YIELD OF SWEET POTATO IN AN ULTISOL AT ABAKALIKI, SOUTHEASTERN NIGERIA.
}

\author{
Ogbodo .E.N.
}

\begin{abstract}
A study was conducted at Abakaliki, southeastern Nigerian during the raining seasons of $2000-2001$. The experiment evaluated the changes in some soil physical properties owing to depth of tillage, and the effect on growth and yield of sweet potato. The tillage depth treatments included zero tillage, $10 \mathrm{~cm}, 20 \mathrm{~cm}, 30 \mathrm{~cm}$ and $40 \mathrm{~cm}$ tillage depths. The soil physical properties measured were bulk density, penetrometer resistance and soil moisture content. Tilling the soil to depths of 20,30 and $40 \mathrm{~cm}$ significantly $(\mathrm{P}=0.05)$ reduced soil bulk density by 13,15 and $22 \%$ respectively when compared with zero tillage. Penetrometer values were 54, 66, 74 and $78 \%$ significantly higher on 10, 20, 30 and $40 \mathrm{~cm}$ tillage depth plots than the untilled plots. The gravimetric moisture content was 20,33 , and $43 \%$ significantly higher in the zero than the 20,30 , and $40 \mathrm{~cm}$ tillage depths respectively. Tilling the soil significantly increased crop growth and yield compared to untilled soil. Plants on the $40 \mathrm{~cm}$ tillage depth produced the highest fresh potato tuber yield of $14.5 \mathrm{t} \mathrm{ha}^{-1}$. The study shows that improving soil physical properties, such as reduced bulk density, increased penetration and good drainage, promotes high crop yield.
\end{abstract}

\section{Key words: Tillage depth, soil properties; Potato yield.}

\section{INTRODUCTION}

Tillage normally involves physical, chemical or biological manipulation of the soil to optimize conditions for seed germination, emergence, and seedling establishment (Lal, 1997). Tillage practices are so widespread that the adequate tillage depth that could lead to optimum crop yield has remained an object of controversy. Ojeniyi and Dexter, (1980) and Maurya, (1986) reported that on certain soils, improper tillage may destroy the structure, leaving conditions which lead to inefficient nutrient utilization. Agboola (1981) and Lal, (1989) observed that the more intensive the tillage operation, the higher the bulk density, whereas Echlers et al (1983) and Varsa et al (1997) reported that bulk density and the rate of penetrometer penetration are linearly related to the depth of tillage operations. The optimum depth of tillage could therefore be said to be location specific. Also, soil types, climate conditions and crop types could also affect the tillage system selected for a location.

At Abakaliki, a major root and tuber crops production area in Nigeria, Yams, (Diascoria sp.), Cassava (Manihot sp.) and Potato (Ipomoea sp) are produced traditionally, making use of local hoes for soil tillage. The farmers make characteristic high mounds for their tuber and root crop production. Mounds of various configurations are made to suit the specie of crops cultivated. The heavy mounds are a measure of circumventing the physical and chemical constraints of these soils which have high bulk density, shallow depth, impervious layer and poor drainage (Nnabude and Mbagwu, 1999). The soils have also been reported to be acidic and of low fertility (Mbagwu and Piccollo, 1990). Making these heavy mounds are labour intensive, costly, reduces land use efficiency and not comparable with mechanization. There is therefore the need for an alternative tillage method to overcome these drawbacks without affecting crops yield.

The objective of the study was to determine the effect of depth of tillage on the soil physical conditions and their influence on growth and yield of sweet potato. 


\section{METHODOLOGY \\ Site Description}

The research was carried out during 200 and 2001 cropping seasons (May - August) at the research and teaching farm of the Ebonyi State University, Abakaliki, located on latitude $6^{0} 19^{\prime} \mathrm{N}$ and Longitude $80^{0} 06^{1} \mathrm{E}$ in the derived savanna zone of the southeastern Nigeria. The Rainy season in the area starts in April and ends in October, leaving a dry spell from October to March. The mean annual rainfall ranges from $1500 \mathrm{~mm}$ to $2000 \mathrm{~mm}$, the mean annual temperature from $26^{\circ}$ to $31^{\circ} \mathrm{C}$, while the humidity ranges from $65-80 \%$ during the rainy season. The soil of the experimental area is hydromorphic, of the order Ultisol within the Ezzamgbo soil association and derived from shale parent material. It is classified as Typic Haplustult (FDALR1985).

\section{Sampling and Analytical procedures}

Prior to establishment of the experiment, six soil auger samples from $0-20 \mathrm{~cm}$ depth (for determination of physical and chemical properties). Six undisturbed soil core samples (for analysis of dry bulk density) and six auger samples (for determination of gravimetric soil water content were randomly collected from 0 to $0.1 \mathrm{~m}$ depth in each plot and used for laboratory analysis. Surface resistance to penetration was determined using a pocket penetrometer model 06.01 from Ejikelkamp Agrisearch Equipment. The resistance to penetration measurement was made to the depth of $0.05 \mathrm{~m}$ at $90^{\circ}$ angle. Measurements for bulk density, penetrometer resistance and gravimetric soil water content were made at 30 days after planting (DAP).

\section{Laboratory Methods}

Soil samples were analyzed for the following: N,P,K, Ca, mg, pH, organic carbon and CEC. Total nitrogen was determined by the macro Kjeldahl method (Bremner and Malvancy 1982). Available $\mathrm{P}$ was determined using Bray II method as outlined in Page et al, (1982), and organic carbon by the Walkley and Black method (Nelson and Sommers, 1982). Soil pH in water was determined by the glass electrode $\mathrm{pH}$ meter (McLean, 1982). The exchangeable bases were determined by the method of the Association of Official analytical chemists (AOAC, 1970). Particle size distribution was determined by the hydrometer method (Gee and Bauder, 1986). Dry bulk density was determined by the core method (Blake and Hartge, 1986). Soil gravimetric moisture was measured using the method outlined by Stolte 1997.

\section{Field Experiment}

The design of the experiment was a randomized complete block design with five treatments and four replications. The treatments comprised of five tillage depths, $0,10 \mathrm{~cm}$, $20 \mathrm{~cm}, 30 \mathrm{~cm}$ and $40 \mathrm{~cm}$ tillage depths. The treatments were randomly applied by the lot method on plots measuring $16 \mathrm{~m}^{2}(4 \mathrm{~m} \mathrm{x} 4 \mathrm{~m})$. The replicates were separated from each other by $1 \mathrm{~m}$ alleys, while $0.5 \mathrm{~m}$ alleys were maintained between the plots.

The tillage operations were manually done each season. Potato variety TIS87/0087 sourced from the National root crops research institute Umudike was the test crop. The potato stems were transplanted one per hole at a spacing of $50 \times 30 \mathrm{~cm}$ and giving a plant population of 5500 stands per hectare. Each plot received a blanket dressing of N.P.K. (10:10:20) $700 \mathrm{~kg} \mathrm{ha}^{-1}$ at 8 weeks after planting.

The agronomic parameters measured, included plant dry matter and fresh tuber yields. Six plant stands were randomly selected from the border rows at $50 \%$ flowering stage in each plot, the shoot harvested, washed and dried in the oven at $65{ }^{\circ} \mathrm{C}$. The means were used for dry matter determination. The fresh tuber yields were determined after harvest at 4 months after planting. 


\section{Data Analysis}

The mean values of the data collected for the two seasons were subjected to statistical analysis using the procedure for analysis of variance (ANOVA) and FLSD as outlined in steel and Torrie, (1980).

\section{RESULTS AND DISCUSSION Soil Properties of the Study Site}

Some soil properties of the study site are summarized in table 1. The textural class for the study site was silty clay loam. The levels of nutrient content of the soil was classified into low, medium or high according to the soil fertility interpretation by London (1991). The low level of organic matter was attributed to the perennial burning of vegetation cover and crop residue. Organic matter is a reservoir of nutrient elements required for crop growth. Their low-level conditions is a negative soil productivity indicator. Asadu and Akamgbo (1990) had reported that soil organic matter contributes an average of $70 \%$ of the cation exchange capacity of Ultisols and Oxisols. The low organic matter level of the soil may have disposed the soil to the observed low $\mathrm{pH}$. The acidic nature of the soil is a major factor to the low soil fertility and could have limited the level of $\mathrm{P}$ in the soil. The soil also had high bulk density and low total porosity. Such soils requires some form of redemption before they could be put to reasonable crop production.

\section{Changes in Soil Physical Properties}

The zero tilled plots had significantly $(\mathrm{P}=0.05)$ higher bulk density when compared with the tilled plots (Table 2). The 20,30, and $40 \mathrm{~cm}$ tillage treatments led to 13,15 and 22\% reduction in soil density when compared with zero tilled plots. Also $40 \mathrm{~cm}$ tillage depth had $14 \%$ lower bulk density than the $10 \mathrm{~cm}$ treated plots. Generally, the deeper the tillage operation the lower the bulk density. Versa et al (1997) reported a higher bulk density in the top layer of untilled soils when compared with tilled soil. Deep tillage could be used to overcome soil compaction characteristic of the study area, and reduce the labour utilized for building the heavy mounds.

Penetrometer penetration was $54,66,74$ and 78 percent significantly $(\mathrm{P}=0.05)$ higher on 10,20,30 and $40 \mathrm{~cm}$ depth of tillage treated plots than the untilled plots. The $30 \mathrm{~cm}$ tillage depth plots had 44 and $25 \%$ significantly higher penetrometer penetration compared to the 10 and $20 \mathrm{~cm}$ depth, and 52 and 36 percent higher on $40 \mathrm{~cm}$ tillage depth than on 20 and $30 \mathrm{~cm}$ treated plots. The surface soil moisture was higher on plots with zero and $10 \mathrm{~cm}$ tillage depths than the 20 and $40 \mathrm{~cm}$ depths.

The higher bulk densities on the zero tilled plots led to reduced pore spaces and water infiltration. The zero till plots had 20,33 and 43\% significantly higher soil moisture than the 20,30 and $40 \mathrm{~cm}$ tillage depth treated plots. The improved soil structure resulting from the 20 $-40 \mathrm{~cm}$ tillage treatments led to improved drainage properties of the soil, which reduced the water logging conditions characteristic of the soils of the study area. Also, evaporation of moisture could be easier in the tilled plots because of easier movement of air, and higher temperature presumably, owing to lower specific heat when compared to the untilled plots.

\section{Crop Growth and Yield}

The effect of depth of tillage on crop growth and yield is presented in figures 1 and 2. Plant shoot dry matter yield was significantly higher on the tilled plots by 16, 24, 27 and $39 \%$ for $10,20,30$ and $40 \mathrm{~cm}$ tillage depths respectively when compared with the untilled plots (Fig 1). The plants in the $40 \mathrm{~cm}$ treated plots produced 23,15 , and $11 \%$ significantly higher dry matter yield than the plants on 10,20 and $30 \mathrm{~cm}$ tillage depth plots, respectively. The improved soil physical conditions due to reduced bulk density, and penetration 
resistance, could have positively influenced the crop growth. The direct implication was that root growth and plant nutrient uptake was increased on tilled plots and this was reflected in the significantly higher plant growth on the tilled plots when compared with the untilled plots. Gantzer and Blake (1978) had also observed that soil density affected water and nutrient movement and root growth.

Fresh tuber yields in the $10 \mathrm{~cm}, 20 \mathrm{~cm}, 30 \mathrm{~cm}$ and $40 \mathrm{~cm}$ soil tillage depth treated plots were 1.2, 6.1, 6.8 and $12.9 \mathrm{tha}^{-1}$ significantly higher than the zero till plots (Fig 2). The linear trend of increase in tuberization in response to depth of tillage underscores the necessity for deep tillage of the soil before planting in the study area. The high soil bulk density observed under the zero till plot apparently reduced plant rooting, elongation, nutrient uptake and plant growth and thus hampered yields. Soil nutrients are absorbed from soil solution near the root tips. Therefore, plants on the tilled plots with greater root area had higher soil feeding area, than those on zero tillage soil. Tillage depth in the study showed that there was profound effect of tillage depth on soil nutrients distribution and availability. This was reflected in the level of tuberisation on the different treatment plots. Chandler et al (1996) and Aina, (1976) also reported higher yields of potato and cassava on tilled plots than the untilled plots. The former observed that higher plant shoot growth was enhanced by the increased root feeding area, created by increased depth of tillage.

\section{CONCLUSION}

The initial soil properties of the experimental site showed that the soil had adverse soil physical and chemical properties. Tilling the soil to a depth of $40 \mathrm{~cm}$ provided optimum soil environment for growth and yield of sweet potato.

Table 1: Properties Of The Soil Of The Experimental Area

\begin{tabular}{lll}
\hline PARAMETERS & & RATING (London 1991) \\
\hline pH $\left(\mathrm{H}_{2} 0\right)$ & 5.18 & Strongly acid \\
Total N $(\%)$ & 0.14 & Low \\
Organic Matter $(\%)$ & 1.53 & Low \\
Available P $\left(\mathrm{mg.} \mathrm{Kg}^{-1}\right)$ & 0.13 & Low \\
Exch. $\mathrm{Mg}\left(\mathrm{Cmol} \mathrm{kg}^{-1}\right)$ & 1.30 & Low \\
Exch. Na $\left(\mathrm{Cmol} \mathrm{kg}^{-1}\right)$ & 0.06 & Low \\
Exch. Ca $\left(\mathrm{Cmol} \mathrm{kg}^{-1}\right)$ & 2.13 & Medium \\
CEC $\left.(\mathrm{Cmol} \mathrm{kg})^{-1}\right)$ & 0.29 & Low \\
Bulk density $\left(\mathrm{gcm}^{-3}\right)$ & 1.57 & High \\
Total porosity $(\%)$ & 41 & Low \\
Sand \% & 24 & \\
Silt \% & 46 & - \\
Clay \% & 32 & - \\
Classification & Silty clay & \\
& loam & \\
\hline
\end{tabular}

Exch $=$ Exchangeable 
JOURNAL OF AGRICULTURE AND SOCIAL RESEARCH (JASR) Vol. 5, No.1, 2005

Table 2: Effect of depth of tillage on some soil physical properties

\begin{tabular}{llll}
\hline \multicolumn{1}{c}{ Penetration } & & Bulk density & \% Moisture \\
\hline $0 \mathrm{~cm}$ & 2.91 & 1.35 & 30 \\
$10 \mathrm{~cm}$ & 6.35 & 1.22 & 28 \\
$20 \mathrm{~cm}$ & 8.46 & 1.17 & 23 \\
$30 \mathrm{~cm}$ & 11.34 & 1.15 & 20 \\
$40 \mathrm{~cm}$ & 13.29 & 1.05 & 17 \\
$\mathrm{LSD}(\mathrm{P}=0.05)$ & 2.56 & 0.14 & 4.26 \\
\hline
\end{tabular}

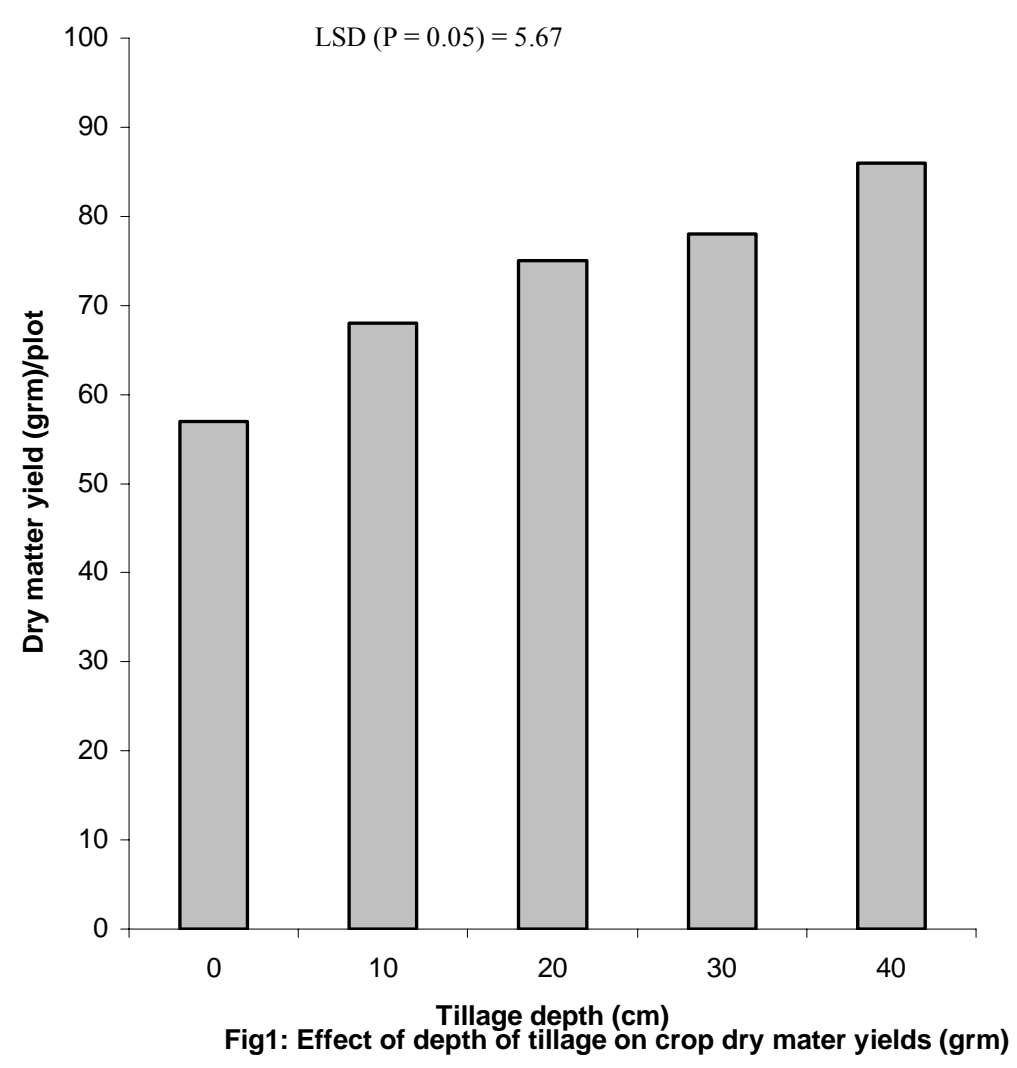




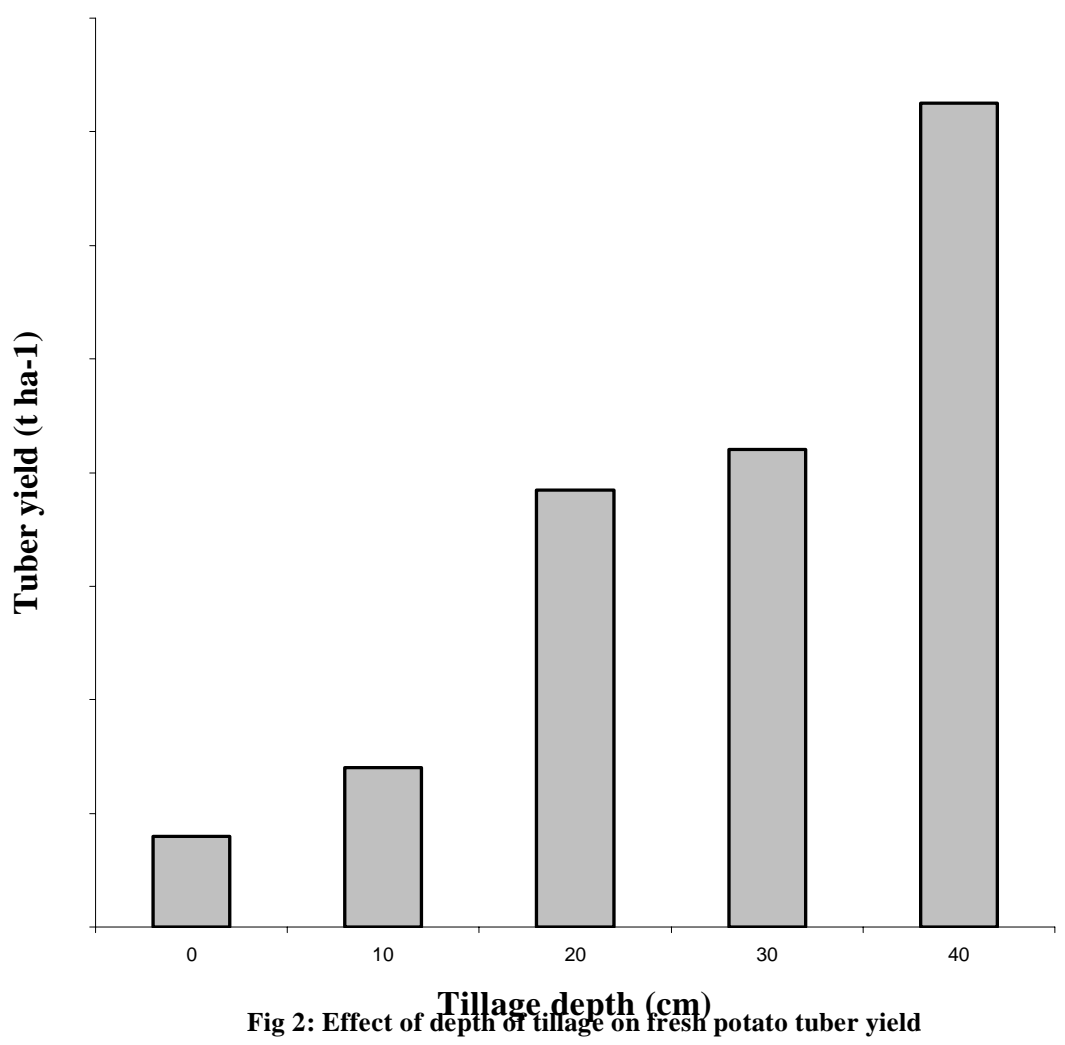

\section{REFERENCES}

Aina, P.O. (1976). Soil changes resulting from Long - Term Management Practices in Western Nigeria. Soil Sci. Soc. Amer. J. 44: 827 - 837

A.O.A.C. (1970). Association of official analytical Chemists; official methods of analysis P.E.D. 11 and 12, Washington, D.C.

Asadu, C.L.A., F.O.R. Akamigbo. (1990). Relative contribution of organic matter and clay fractions to cation exchange capacity of soils in southeastern Nigeria. Samaru Journal of Agricultural. Resarch 7: $17-23$.

Blake, G.R. and K.H Hartge (1986). Bulk density. Methods of soil analysis, part 1. Physical and mineralogical methods. A klute (ed). Am. Soc. Agron. Madison, 101 USA: 365 $-375$

Bremener, J.M. and C.S. Mulvancy, 1982. Total Nitrogen. In Page, A.L., R.H. Miller and D.R. Keenney. Methods of soil analysis. 2. Chemical and microbiological properties. Agronomy Monograph No. 9 ( $2^{\text {nd }}$ ed) Madison, Wisconsim, USA: American Soc. Of Agronomy.

Chandler, J.V., R.C. Costar and E.G. Boneta (1996). High crop produced with and without tillage on three tropical soils of the humid region of Puerto Rico. Fac. Agric. Univ. of Puerto Rico bulletin 50: 146 - 150.

Echlers, W., U. Kopke, F. Hosse and W. Bohm (1983). Penetration resistance and root growth of Oats in tilled and untilled loose soil. Soil and tillage Research, 2: $261-275$. 
FDALR (1985). Reconnaissance soil Survey of Anambra State, Nigeria. Soils Report, FDALR, Kaduna.

Gantzer, G.J. and G.R. Blake 1978. Physical Characteristics of Le Sueur Clay Loam Soil following no - Tillage and conventional Tillage. Agron J. 70: 853 - 857

Gee, G. W. And J.W. Bauder (1986). Particle size analysis. In: Methods of Soil analysis. Part 1. A Klute (ed). Am. Soc. Agron. Madison 101. USA: 383 - 41.

Lal, R. (1989). Conservation tillage for sustainable Agriculture; tropics vs temperature environments. Adv. Agron. 42: 85 - 197.

Lal, R. (1997). Long term Tillage and Maize Monoculture effects on a tropical Alfsol in Western Nigeria. Soil and tillage Research. 1997, 42: 145 - 160.

Landon, J.R. (ed) (1991). Booker Tropical Soil Manual: A handbook for soil survey and agricultural land evaluation in the tropics and subtropics. John Wiley and Sons Inc., 605 Third Avenue, New York, USA. 474pp.

Mbagwu J.S.C and A. Piccollo (1990). Carbon, Nitrogen and Phosphorus Concentration in aggregates of a waste amended soil. Biological Wastes 31: $97-111$.

Mclean, E.O. (1982). Soil pH and Lime requirement. In: Methods of soil analysis Part 2. Agronomy. A.L. Page (ed) Am. Soc. Agron. Madison, 101. USA: 199 - 234

Nelson, D. W. and L.E. Sommers (1982). Total Carbon, Organic Carbon and Organic Matter. Methods of soil analysis. Part 2. Chemical and Microbiological properties. ASA, Madison. WI: 359 - 580

Nnabude, P.C. and J.S.C. Mbagwu (1999). Soil water relations of a Nigerian typic haplustult amended with fresh and burnt rice mill wastes. Soil and tillage Research, 50 :207214

Ojeniyi, S.O. and R. A Dexter (1985): Changes in the structure of tilled soil in a growing season. Soil and Tillage Research 3: $39-46$

Page, A. L., R. H. Miller and D. R. Keeney (1982) Methods of soil analysis. Part 2. Chemical and microbiological properties. ASA Madison

Steel, G.D. and J.H. Torrie (1980). Principles and procedures of statistics. A biometrics approach. $2^{\text {nd }}$ Ed. Mcgraw - Hill book company Inc. New - York: 633

Stolte J. (Ed.) 1997 Manual of Soil Physical Measurements. Version 3. Wageningen, D.L.O. Staring Centre, Tech. Doc. 37.

Versa, E.C., S.K. Chong, J.O. Abolaji, D. A. Fargular and J.J. Olsen (1997). Effect of deep tillage on soil physical characteristics and corn root growth and production. Soil and Tillage Research, 1997, 43; 3-4: $219-228$ 